\title{
Multivalent niacin nanoconjugates for delivery to cytoplasmic lipid droplets
}

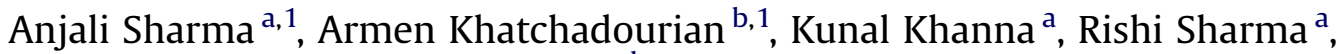 \\ Ashok Kakkar ${ }^{\mathrm{a}, *}$, Dusica Maysinger ${ }^{\mathrm{b}, * *}$ \\ ${ }^{a}$ Department of Chemistry, McGill University, 801 Sherbrooke St. West, Montreal, Quebec H3A 2K6, Canada \\ ${ }^{\mathrm{b}}$ Department of Pharmacology and Therapeutics, McGill University, 3655 Promenade Sir-William-Osler, Montreal, Ouebec H3G 1Y6, Canada
}

\section{A R T I C L E I N F O}

\section{Article history:}

Received 2 September 2010

Accepted 12 October 2010

Available online 10 November 2010

\section{Keywords:}

Multifunctional nanocarriers

Dendrimers

Drug delivery

Niacin

Targeting lipid droplets

\begin{abstract}
A B S T R A C T
We report here the design, synthesis, and properties, of multifunctional niacin nanoconjugates based on dendritic, miktoarm and linear backbone nanocarriers, using "click" chemistry. The conjugates were in this instance used to deliver the therapeutic agent niacin to lipid droplets. The desired combination of niacin, a lipophilic fluorescent dye (BODIPY), and polyethylene glycol (PEG), was achieved by covalently linking the desired agents to the selected carrier. The nanocarriers containing niacin and BODIPY were found almost exclusively within cytoplasmic lipid droplets in the cells used in this study (living hepatocytes and microglia), whereas the trifunctional carrier containing niacin, BODIPY and PEG was partially localized within these organelles but also elsewhere in the cytoplasmic compartment. Spectrofluorometric analyses, confocal microscopy and fluorescence cell sorting revealed different rates and extent of multifunctional conjugate(s) internalization in the two cell types. Even micromolar concentrations of the internalized multifunctional conjugates did not cause significant cell death or mitochondrial functional impairment, suggesting that they are suitable candidate nanostructures for lipid droplet imaging and for targeting drugs to these cellular organelles. These studies provide an efficient and easy way to synthesize multifunctional nanocarriers by click chemistry, applicable to the synthesis of related multifunctional nanostructures and to their use in the targeting of cellular organelles, including lipid droplets.
\end{abstract}

() 2010 Elsevier Ltd. All rights reserved.

\section{Introduction}

Efficient delivery of therapeutics and simultaneous imaging of their targeted intracellular locations using materials of nanodimensions continues to be a topical area of research in biotechnology $[1,2]$. Challenges in the design and construction of such multivalent carriers have included developing synthetic methodologies that could deliver orthogonally functionalized architectures, an evaluation of their biocompatibility, monitoring the delivery to specific sites across cell membranes, and determining their therapeutic efficiency with improved pharmacokinetics [3]. Among numerous nanostructures that have been currently studied for combining drug delivery with tissue imaging, functionalized dendrimers and miktoarm polymers offer tremendous potential due to their unique architecture and properties [4]. Dendrimers are hyperbranched macromolecules, structurally versatile (can be tailored to a wide range of nanodimensions), and are monodisperse in nature

\footnotetext{
* Corresponding author. Tel.: +1 514398 6912; fax: +1 5143983797.

** Corresponding author. Tel.: +1 514398 1264; fax: +1 5143986690 .

E-mail addresses: ashok.kakkar@mcgill.ac (A. Kakkar), dusica.maysinger@ mcgill.ac (D. Maysinger).

1 These authors contributed equally to this work.
}

with well-defined particle size [5]. Dendrimers are a recent addition to the field of nanomedicine, and they are currently being developed together with polymeric macromolecules as nanodevices for therapeutic applications [6]. We demonstrate here that such biocompatible nanovectors that can carry a combination of therapeutics and organelle imaging agents can be easily constructed using a highly efficient synthetic methodology based on $\mathrm{Cu}^{\mathrm{I}}$ catalyzed alkyne-azide cycloaddition "click" chemistry [7-10]. This 1,3-dipolar Huisgen cycloaddition is a versatile synthetic tool in constructing multifunctional nanomaterials with orthogonal functionalities which offer tremendous potential for applications in biology [11].

Targeting of drugs by designed delivery systems (DDS) to specific subcellular compartments could prove a valid approach to achieve greater drug efficacy and specificity [12-14]. Herein, we describe a novel macromolecule-based nanodelivery system for niacin to specifically target lipid droplets (LDs). In the context of liver cells (hepatocytes), a designed DDS may provide specificity by carrying niacin directly to its target, DGAT2, localized on LDs. The mechanism of transport of niacin in hepatocytes was studied and shown to be regulated by specific membrane carriers systems [15]. Niacin, covalently attached to the nanocarrier by an ester bond, can only be released when the bond is cleaved off by cellular esterases. The detection of the polymers at the subcellular level was made possible 
by attaching a lipophilic fluorescent dye, BODIPY. One particular non-polar derivative of BODIPY, Bodipy 493/503, is commonly used for staining intracellular LDs [16].

Niacin/nicotinic acid (Vitamin $B_{3}$ ) is well known for its potential to improve lipid profile in patients with abnormalities including hyperlipidemia [17], and to treat atherosclerosis and reduce risks for cardiovascular disease [18-20]. Niacin is the most effective agent for increasing high density lipoprotein cholesterol (HDL-C) levels and concomitantly reducing low density cholesterol (LDL-C) and triglycerides in patients with dyslipidemia [18]. Niacin exerts most of its biological effects in cells by binding with high affinity to the Gprotein coupled receptor GPR109a/HM74a [21-24]. Mechanisms of action of niacin [19] include the inhibition of lipolysis in adipocytes and inhibition of hepatic diacylglycerol acyltransferase 2 (DGAT2), the enzyme involved in the final step of triglyceride biosynthesis [25]. Triglycerides are stored in intracellular lipid droplets (LDs), organelles specialized in lipid storage and fatty acid mobilization [26]. DGAT2 was shown to colocalize with LDs in adipoctes [27,28] Excessive LD accumulation linked with hepatic steatosis and inflammation [29] could likely be reduced by targeting LD or LDassociated proteins with suitable nanocarriers. The objective of the study reported here was to develop multifunctional materials for targeting niacin to LDs and to show if the designed nanocarriers colocalized with these organelles.

\section{Materials and methods}

\subsection{Materials}

Copper (II) sulfate pentahydrate $\left(\mathrm{CuSO}_{4} \cdot 5 \mathrm{H}_{2} \mathrm{O}\right)$ (>98.0\%), sodium ascorbate (NaAsc) (crystalline) (98\%), 6-Bromohexanoic acid (97\%), 11-Bromo-1-undecanol (98\%), Niacin (NA) (>99\%), 1-[3-(Dimethylamino)propyl]-3-ethylcarbodiimide methiodide(EDC), 4(dimethylamino)pyridine (DMAP) (99\%), and sodium azide $(\mathrm{NaN} 3)$ ( $>99.5 \%)$ were purchased from Sigma-Aldrich Canada, and used as received. 8-Acetoxymethyl-2,6-diethyl -1,3,5,7-tetramethyl pyrromethene fluoroborate (PM605) was purchased from Exciton Inc, and used as received. All other solvents were used as received in their anhydrous forms. NMR spectra were recorded on a 400 or $500 \mathrm{MHz}$ (as specified) spectrometer at ambient temperatures. The chemical shifts in ppm are reported relative to tetramethylsilane as an internal standard for ${ }^{1} \mathrm{H}$ and ${ }^{13} \mathrm{C}\left\{{ }^{1} \mathrm{H}\right\}$ NMR spectra. Mass spectra were recorded on Thermo Scientific Orbitrap mass analyzer (ES) and Kratos MS25 (EI) mass spectrometers, and MALDI-TOF spectra on Autoflex III Mass Spectrometer (Bruker) using LiBr-dithranol as the matrix.

\subsection{Synthesis}

The following compounds were synthesized by adaptation of the previously published procedure as follows: 1,3,5-triethynyl benzene [30], 11-Azido-undecan-1ol [31], PEG 750 -Azide [32], Miktoarm carrier containing $\mathrm{PEG}_{750}$, acetylene and benzylic alcohol [32]. Miktoarm carrier containing two PEG $_{750}$ chains and a benzylic alcohol group [33]. BODIPY-Azide, Linear unit containing long chain alcohol and an acetylenic arm, and the dendrimer containing the long chain alcohol arms and free acetylenic groups [31].

\subsubsection{Synthesis of dendrimer containing niacin and free acetylenic arms (3)}

To a solution of dendrimer containing long chain alcohol and free acetylene (100 mg, $0.073 \mathrm{mmol}), 1$-[3-(dimethylamino)propyl]-3-ethylcarbodiimide methiodide (130.5 mg, $0.439 \mathrm{mmol}$ ), 4-(dimethylamino)pyridine (14 mg, $0.115 \mathrm{mmol}$ ), pyridine $(1 \mathrm{~mL})$ in anhydrous ( $2 \mathrm{~mL})$ DMF, nicotinic acid $(54.11 \mathrm{mg}, 0.439 \mathrm{mmol})$ was added, and the solution was stirred at room temperature for $24 \mathrm{~h}$. Water $(40 \mathrm{~mL})$ was then added, and extraction of the product was carried using dichloromethane $(3 \times 20 \mathrm{~mL})$. The combined organic extracts were then washed with water and brine, dried over sodium sulphate and concentrated under reduced pressure. The crude product was then passed through a column of silica gel. The pure fractions of product were obtained using 5\% methanol in dicholoromethane (DCM) as an eluent. The fractions were then concentrated to give the desired product as a white solid. (120 mg, 100\%). ${ }^{1} \mathrm{H}$ NMR (400 MHz, $\left.\mathrm{CDCl}_{3}\right): \delta(\mathrm{ppm}) 1.21-1.44\left(\mathrm{~m}, 42 \mathrm{H},-\mathrm{CH}_{2}-\right), 1.62-$ $1.82\left(\mathrm{~m}, 6 \mathrm{H},-\mathrm{CH}_{2} \mathrm{CH}_{2} \mathrm{OH}\right), 1.82-2.02\left(\mathrm{~m}, 6 \mathrm{H},-\mathrm{CH}_{2} \mathrm{CH}_{2}\right.$-triazole), 3.11 (s, 3H, ArCCH), 4.22-4.34 (m, 6H, - $\mathrm{CH}_{2} \mathrm{OCO}-$ ), 4.34-4.42 (m, 6H, $-\mathrm{CH}_{2} \mathrm{CH}_{2}$-triazole), 5.58 (s, 6H, -ArCH $\mathbf{H}_{2}$-triazole), $7.36(\mathrm{~s}, 3 \mathrm{H}, \mathrm{ArH}), 7.36-7.41(\mathrm{~m}, 3 \mathrm{H}, \mathrm{ArH}), 7.79(\mathrm{~s}, 3 \mathrm{H}$, triazoleH), 7.82 (s, 3H, ArH), 7.86 (s, 3H, ArH), 7.93 (s, 3H, ArH, core), 8.19 (s, 3H, triazoleH, core), 8.25-8.30 (m, 3H, ArH), 8.75-8.77 (m, 3H, ArH), 9.20-9.21 (m, 3H, ArH). ${ }^{13} \mathrm{C}\left\{{ }^{1} \mathrm{H}\right\}$ NMR $\left(125 \mathrm{MHz}, \mathrm{CDCl}_{3}\right): \delta$ ppm 25.9, 26.4, 28.6, 28.9, 29.2, 29.3, 29.4, 30.3, 50.5, 53.8, 50.5,
53.8, 65.5, 78.6, 82.4, 120.0, 120.2, 122.4, 123.3, 123.9, 125.6, 129.6, 130.9, 131.6, 132.1, 135.4, 136.9, 145.9, 147.6, 150.9, 153.3 and 165.3. ESI-MS: m/z $1701.82\left([\mathrm{M}+\mathrm{Na}]^{+}\right)$.

\subsubsection{Synthesis of dendrimer containing niacin and BODIPY (4)}

Compound 3 (102 mg, $0.062 \mathrm{mmol}$ ) and BODIPY-azide (131.7 mg, $0.278 \mathrm{mmol}$ ) were dissolved in $2 \mathrm{~mL}$ of THF, followed by addition of sodium ascorbate $(5 \mathrm{mg}$, $0.03 \mathrm{mmol})$. An aqueous solution $(1 \mathrm{~mL})$ of $\mathrm{CuSO}_{4} .5 \mathrm{H}_{2} \mathrm{O}(3.0 \mathrm{mg}, 0.01 \mathrm{mmol})$ was added dropwise to the solution. The reaction mixture was left to stir overnight at room temperature. THF was then evaporated, and the remaining solution was extracted with DCM $(3 \times 20 \mathrm{~mL})$, and then the organic layer was extracted with brine $\left(3 \times 50 \mathrm{~mL}\right.$ ). It was dried over $\mathrm{MgSO}_{4}$, and the solvent was evaporated. Silicagel column chromatography was used to isolate the product with $5 \%$ methanol in DCM. The solvent was evaporated to yield the product as a red solid (120 mg, 65\%). ${ }^{1} \mathrm{H}$ NMR (400 MHz, $\left.\mathrm{CDCl}_{3}\right): \delta(\mathrm{ppm}) 0.98\left(\mathrm{t}, 18 \mathrm{H},-\mathrm{ArCH}_{2} \mathrm{CH}_{3}\right), 1.20-1.40(\mathrm{~m}, 48 \mathrm{H}$ $-\mathrm{CH}_{2}$-), 1.60-1.70 (m, $\left.6 \mathrm{H},-\mathrm{CH}_{2} \mathrm{CH}_{2} \mathrm{OH}\right), 1.70-1.80$ ( $\mathrm{m}, 6 \mathrm{H},-\mathrm{CH}_{2} \mathrm{CH}_{2} \mathrm{CH}_{2}$-triazole), 1.80 $1.96\left(\mathrm{~m}, 12 \mathrm{H},-\mathrm{CH}_{2} \mathrm{CH}_{2}\right.$-triazole), $2.18\left(\mathrm{~s}, 18 \mathrm{H},-\mathrm{ArCH}_{3}\right), 2.24-2.38\left(\mathrm{~m}, 18 \mathrm{H},-\mathrm{CH}_{2}\right.$ ) , $2.46\left(\mathrm{~s}, 18 \mathrm{H},-\mathrm{ArCH}_{3}\right), 4.28-4.35\left(\mathrm{~m}, 6 \mathrm{H},-\mathrm{CH}_{2} \mathrm{OH}\right), 4.35-4.40\left(\mathrm{~m}, 12 \mathrm{H},-\mathrm{CH}_{2} \mathrm{CH}_{2}\right.$-triazole), 5.27 (s, 6H, $\left.-\mathrm{ArCH}_{2} \mathrm{OOCCH}_{2}-\right), 5.60$ (s, 6H, - $\mathrm{ArCH}_{2}$-triazole), 7.39 (s, 3H, ArH) 7.35-7.40 (m, 3H, ArH), 7.76 (s, 3H, triazoleH), 7.79 (s, 3H, ArH, core), 7.87 (s, 6H, ArH), $8.14(\mathrm{~s}, 3 \mathrm{H}$, triazoleH, BODIPY arm), 8.14-8.29 (m,3H, $\operatorname{ArH}), 8.29(\mathrm{~s}, 3 \mathrm{H}$, triazoleH,core), 8.75-8.76 (m,3H, ArH), 9.20-9.21 (m,3H, ArH). ${ }^{13} \mathrm{C}\left\{{ }^{1} \mathrm{H}\right\}$ NMR (125 MHz, $\left.\mathrm{CDCl}_{3}\right): \delta(\mathrm{ppm}) 12.6,14.7,17.1,22.7,24.2,24.9,25.6,25.9,26.5,28.6,28.9,29.2,29.3$ 29.4, 29.7, 29.9, 30.3, 31.9, 33.6, 33.9, 50.1, 50.5, 54.1, 58.2, 65.6, 120.2, 120.3, 122.3, 124.8, 131.6, 132.2, 132.4, 133.5, 135.8, 136.5, 137.0, 146.5, 146.6, 147.4, 150.8, 153.3, 154.9, 165.3 and 172.8. MALDI: $\mathrm{m} / \mathrm{z} 3074.34\left([\mathrm{M}+\mathrm{Li}]^{+}\right)$.

\subsubsection{Synthesis of the linear compound containing niacin and free acetylene (6)}

To a solution of the linear compound containing long chain alcohol and the free acetylene (200 mg, $0.590 \mathrm{mmol}$ ), 1-[3-(dimethylamino)propyl]-3-ethylcarbodiimide methiodide (350.4 mg, $1.180 \mathrm{mmol}$ ), 4-(dimethylamino)pyridine (36 mg, $0.295 \mathrm{mmol})$, pyridine $(0.5 \mathrm{~mL})$ in anhydrous $(2 \mathrm{~mL}) \mathrm{DMF}$, nicotinic acid (145.3 $\mathrm{mg}$, $1.180 \mathrm{mmol}$ ) was added, and the solution was stirred at room temperature for $24 \mathrm{~h}$. Water $(30 \mathrm{~mL})$ was then added, and the product was extracted using DCM $(3 \times 20 \mathrm{~mL})$. The combined organic extracts were then washed with water and brine, dried over sodium sulphate and concentrated under reduced pressure. The crude mixture was then passed through a column of silica gel. The pure fractions of product were obtained using 5\% methanol in DCM as an eluent. The fractions were then concentrated to afford the product as a white solid. (260 mg, 94\%). ${ }^{1} 1 \mathrm{H} \mathrm{NMR}$ $\left(400 \mathrm{MHz}, \mathrm{CDCl}_{3}\right): \delta(\mathrm{ppm}) 1.34-1.40\left(\mathrm{~m}, 12 \mathrm{H},-\mathrm{CH}_{2^{-}}\right), 1.40-1.43\left(\mathrm{~m}, 2 \mathrm{H},-\mathrm{CH}_{2} \mathrm{CH}_{2} \mathrm{OH}\right)$, 1.75-1.80 (m, $2 \mathrm{H},-\mathrm{CH}_{2} \mathrm{CH}_{2} \mathrm{CH}_{2}$-triazole), 1.92-1.96 ( $\mathrm{m}, 2 \mathrm{H},-\mathrm{CH}_{2} \mathrm{CH}_{2}$-triazole), 3.13 (s, $1 \mathrm{H},-\mathrm{CCH}), 4.34$ (t, 2H, - $\left.\mathrm{CH}_{2} \mathrm{OCO}-\right), 4.40$ (t, 2H, - $\mathrm{CH}_{2}$-triazole), 7.39-7.42 (m, 1H, ArH), 7.55 (d, 2H, ArH), 7.78 (d, 2H, ArH), $7.81(\mathrm{~s}, 1 \mathrm{H}$, triazoleH), 8.28-8.31 (m, 1H, ArH), 8.76-8.78 (m,1H, ArH ), 9.22-9.93 (m,1H, ArH). 13C $\{1 \mathrm{H}\}$ NMR $\left(125 \mathrm{MHz}, \mathrm{CDCl}_{3}\right)$ : $\delta(\mathrm{ppm}) 25.9,26.5,28.6,29.0,29.2,29.3,29.4,30.3,50.5,65.5,77.8,83.5,119.7,121.6$, $123.2,125.4,126.3,131.1,132.6,137.0,147.0,150.9,153.3$ and 165.3. ESI-MS: $\mathrm{m} / \mathrm{z}$ $467.24\left([\mathrm{M}+\mathrm{Na}]^{+}\right), 445.26\left([\mathrm{M}+\mathrm{H}]^{+}\right)$.

\subsubsection{Synthesis of the linear compound containing niacin and BODIPY dye (7)}

Linear compound containing niacin and free acetylene (6) (60 mg, $0.135 \mathrm{mmol}$ ) and BODIPY-azide ( $96 \mathrm{mg}, 0.203 \mathrm{mmol}$ ) were dissolved in $2 \mathrm{~mL}$ of THF, followed by addition of sodium ascorbate $(5 \mathrm{mg}, 0.03 \mathrm{mmol})$. An aqueous solution $(1 \mathrm{~mL})$ of $\mathrm{CuSO}_{4} .5 \mathrm{H}_{2} \mathrm{O}(3.0 \mathrm{mg}, 0.01 \mathrm{mmol})$ was added dropwise to the solution. The reaction mixture was left to stir overnight at room temperature. THF was then evaporated, and the remaining solution was extracted with DCM $(3 \times 20 \mathrm{~mL})$, and then the organic layer was extracted with brine $(3 \times 50 \mathrm{~mL})$. It was dried over $\mathrm{MgSO}_{4}$, and the solvent was evaporated. Silica-gel column chromatography was used to isolate the product with $5 \%$ methanol in DCM. The solvent was evaporated to yield the product as a red solid (100 mg, 81\%). ${ }^{1} \mathrm{H}$ NMR $\left(400 \mathrm{MHz}, \mathrm{CDCl}_{3}\right): \delta(\mathrm{ppm}) 1.02(\mathrm{t}, 6 \mathrm{H}$, $\left.-\mathrm{ArCH}_{2} \mathrm{CH}_{3}\right), 1.25-1.34\left(\mathrm{~m}, 14 \mathrm{H},-\mathrm{CH}_{2}-\right), 1.34-1.42\left(\mathrm{~m}, 2 \mathrm{H},-\mathrm{CH}_{2} \mathrm{CH}_{2} \mathrm{OH}\right), 1.50-1.70(\mathrm{~m}$, $4 \mathrm{H},-\mathrm{CH}_{2} \mathrm{CH}_{2} \mathrm{CH}_{2}$-triazole), 1.70-2.00 (m, $4 \mathrm{H},-\mathrm{CH}_{2} \mathrm{CH}_{2}$-triazole), 2.22 (s, $6 \mathrm{H},-\mathrm{ArCH}_{3}$ ), $2.30-2.40\left(\mathrm{~m}, 6 \mathrm{H},-\mathrm{OOCCH}_{2-},-\mathrm{ArCH}_{2} \mathrm{CH}_{3}\right), 2.49\left(\mathrm{~s}, 6 \mathrm{H},-\mathrm{ArCH}_{3}\right), 3.64\left(\mathrm{t}, 2 \mathrm{H},-\mathrm{CH}_{2} \mathrm{OH}\right)$, 4.32-4.40 (m, $4 \mathrm{H},-\mathrm{CH}_{2}$-triazole), $5.30\left(\mathrm{~s}, 2 \mathrm{H},-\mathrm{ArCH}_{2} \mathrm{OOCCH}_{2}-\right), 7.39(\mathrm{~m}, 1 \mathrm{H}, \mathrm{ArH})$, $7.79(\mathrm{~s}, 2 \mathrm{H}$, triazoleH), $7.89(\mathrm{~s}, 4 \mathrm{H}, \mathrm{ArH}), 8.27-8.30(\mathrm{~m}, 1 \mathrm{H}, \mathrm{ArH}), 8.76-8.77(\mathrm{~m}, 1 \mathrm{H}$, ArH) and 9.21-9.23 (m, $1 \mathrm{H}, \mathrm{ArH}) ;{ }^{13} \mathrm{C}\left\{{ }^{1} \mathrm{H}\right\} \operatorname{NMR}\left(125 \mathrm{MHz}, \mathrm{CDCl}_{3}\right): \delta(512.6,14.7,15.3$, $17.1,24.2,25.9,26.5,28.6,29.2,29.3,29.4,29.9,30.3,33.7,50.0,50.5,58.2,65.6,119.4$, $119.5,123.3,126.0,130.3,130.4,131.5,132.2,133.6,136.4,136.9,147.3,147.4,150.8$, 153.3, 155.0 and 172.9. ESI-MS : $m / z 940.52\left([\mathrm{M}+\mathrm{Na}]^{+}\right)$.

\subsubsection{Synthesis of miktoarm carrier containing $P E G_{750}, B O D I P Y$ and benzylic alcohol (9)}

A concentrated solution of the miktoarm carrier containing $\mathrm{PEG}_{750}$, acetylene and benzylic alcohol $(0.196 \mathrm{~g}, 0.201 \mathrm{mmol})$ and BODIPY-azide $(0.1 \mathrm{~g}, 0.211 \mathrm{mmol})$ in THF $(2.5 \mathrm{~mL})$ was prepared and stirred to dissolution in a round-bottom flask. Sodium Lascorbate ( $4.190 \mathrm{mg}, 0.021 \mathrm{mmol}$ ) was then added to the flask. $\mathrm{CuSO}_{4} .5 \mathrm{H}_{2} \mathrm{O}(3.70 \mathrm{mg}$, $0.148 \mathrm{mmol}$ ) was dissolved in $0.5 \mathrm{~mL}$ of distilled water and added dropwise to the above mixture. A condenser was attached to the apparatus, reaction was placed under nitrogen and allowed to stir for $36 \mathrm{~h}$ in the dark. The contents of the flask were then added directly to a column where it was purified by silica gel column chromatography using a mixture of methanol and dichloromethane (1:5). The solvent was then 
evaporated and a dark red oil was recovered $(0.150 \mathrm{~g}, 53 \%) .{ }^{1} \mathrm{H} \mathrm{NMR}\left(500 \mathrm{MHz}, \mathrm{CDCl}_{3}\right)$ : $\delta(\mathrm{ppm}) 1.02\left(\mathrm{t}, 6 \mathrm{H},-\mathrm{CH}_{2} \mathrm{CH}_{3}\right), 1.41\left(\mathrm{~m}, 2 \mathrm{H},-\mathrm{AcO}-\mathrm{CH}_{2} \mathrm{CH}_{2}-\right), 1.72\left(\mathrm{~m}, 2 \mathrm{H},-\mathrm{AcO}-\mathrm{CH}_{2-}\right.$ $\left.\mathrm{CH}_{2}-\mathrm{CH}_{2}-\right), 1.97\left(\mathrm{~m}, 2 \mathrm{H},-\mathrm{Tri}-\mathrm{Az}-\mathrm{CH}_{2}-\mathrm{CH}_{2}\right), 2.22\left(\mathrm{~s}, 6 \mathrm{H}, \mathrm{CH}_{3}-\right), 2.36\left(\mathrm{~m}, 2 \mathrm{H},-\mathrm{AcO}-\mathrm{CH}_{2}-\right)$, $2.38\left(\mathrm{~m}, 4 \mathrm{H}, \mathrm{CH}_{3} \mathrm{CH}_{2}-\right), 2.48\left(\mathrm{~s}, 6 \mathrm{H}, \mathrm{CH}_{3}-\right), 3.25$ (t, $\left.2 \mathrm{H},-\mathrm{TriAz}^{-} \mathrm{CH}_{2}-\right), 3.36$ (s, 3H, -PEG$\mathrm{OCH}_{3}$ ), 3.53-3.63 (br, PEG), 3.91 (t, 2H, - PEG-CH $-\mathrm{CH}_{2}$-TriAz-), 4.59 (t, 2H, -PEG-CH $\mathrm{CH}_{2}$-TriAz-), 4.77 (s, 2H, - $\mathrm{ArCH}_{2} \mathrm{OH}$ ), 5.31 (s, 2H, - $\left.\mathrm{CH}_{2}-\mathrm{AcO}-\right), 7.81$ (s, $\left.1 \mathrm{H}, \mathrm{ArH}\right), 7.85$ (s, $1 \mathrm{H}, \operatorname{ArH}), 7.91(\mathrm{~s}, 1 \mathrm{H}, \mathrm{ArH}), 8.14(\mathrm{~s}, 1 \mathrm{H}, \operatorname{TriAz}-\mathrm{H}), 8.23(\mathrm{~s}, 1 \mathrm{H}, \operatorname{TriAz}-\mathrm{H}) ;{ }^{13} \mathrm{C}\left\{{ }^{1} \mathrm{H}\right\} \mathrm{NMR}$ (125 MHz, $\left.\mathrm{CDCl}_{3}\right): \delta(\mathrm{ppm}) 12.6,13.6,14.7,17.1,19.7,24.0,24.2,25.9,29.9,33.6,50.0$, 50.4, 58.3, 59.0, 64.7, 69.4, 70.3, 70.5, 72.0, 72.5, 120.1, 121.5, 121.8, 123.5, 123.7, 131.3, $131.5,132.2,133.6,136.5,142.7,147.2,147.4,154.9$, and 172.9 .

\subsubsection{Synthesis of miktoarm carrier containing PEG $750, B O D I P Y$ and niacin (10)}

To a solution of $\mathbf{9}(0.150 \mathrm{~g}, 0.01068 \mathrm{mmol})$ and 4-dimethylaminopyridine (13 $\mathrm{mg}$ $0.1068 \mathrm{mmol})$ in DCM (3 mL), nicotinic acid $(19.7 \mathrm{mg}, 0.1602 \mathrm{mmol})$ was added. Once the solid was fully dissolved, 1-ethyl-3-(3-dimethylaminopropyl)carbodiimide (63 mg, $0.2136 \mathrm{mmol}$ ) was added and the solution was stirred under nitrogen overnight at room temperature in the dark. The reaction mixture was then added directly into a column and purified by silica gel column chromatography using a mixture of methanol and dichloromethane (1:20). The solvent was evaporated to yield a red oil $(25 \mathrm{mg}, 16 \%) .{ }^{1} \mathrm{H}$ $\operatorname{NMR}\left(400 \mathrm{MHz}, \mathrm{CDCl}_{3}\right): \delta(\mathrm{ppm}) 1.04\left(\mathrm{t}, 6 \mathrm{H},-\mathrm{CH}_{2} \mathrm{CH}_{3}\right), 1.46\left(\mathrm{~m}, 2 \mathrm{H},-\mathrm{AcO}-\mathrm{CH}_{2} \mathrm{CH}_{2}-\right), 1.69$ (m, $\left.2 \mathrm{H},-\mathrm{AcO}-\mathrm{CH}_{2}-\mathrm{CH}_{2}-\mathrm{CH}_{2}-\right), 1.99\left(\mathrm{~m}, 2 \mathrm{H},-\mathrm{TriAz}-\mathrm{CH}_{2}-\mathrm{CH}_{2}\right), 2.22\left(\mathrm{~s}, 6 \mathrm{H}, \mathrm{CH}_{3}-\right), 2.36$ (m, $\left.2 \mathrm{H},-\mathrm{AcO}-\mathrm{CH}_{2}-\right), 2.38$ ( $\mathrm{m}, 4 \mathrm{H}, \mathrm{CH}_{3} \mathrm{CH}_{2}$ ), 2.49 (s, 6H, $\mathrm{CH}_{3}$ ), 3.25 (t, $2 \mathrm{H},-\mathrm{TriAz}-\mathrm{CH}_{2}$ ), 3.36 (s, 3H, -PEG-OCH 3 ), 3.53-3.63 (br, PEG), 3.94 (t, 2H, -PEG-CH CH$_{2}-\mathrm{CH}_{2}$-TriAz-), 4.59 (t, $2 \mathrm{H},-\mathrm{PEG}-\mathrm{CH}_{2}-\mathrm{CH}_{2}$-TriAz-), 5.31 (s, 2H, - $\left.\mathrm{CH}_{2}-\mathrm{AcO}-\right), 5.52$ (s, $2 \mathrm{H},-\mathrm{ArCH}_{2} \mathrm{OH}$ ), 7.50 $(\mathrm{s}, 1 \mathrm{H}$, Pyr-H) $7.94(\mathrm{~s}, 1 \mathrm{H}, \mathrm{ArH}), 7.96(\mathrm{~s}, 2 \mathrm{H}, \mathrm{ArH}), 8.14(\mathrm{~s}, 1 \mathrm{H}, \mathrm{TriAz}-\mathrm{H}), 8.26(\mathrm{~s}, 1 \mathrm{H}$, TriAzH), 8.42 (s, 1H, Pyr-H), 8.8 (s, 1H, Pyr-H), 9.27 (s, 1H, Pyr-H); ${ }^{33} \mathrm{C}\left\{{ }^{1} \mathrm{H}\right\}$ NMR $(125 \mathrm{MHz}$, $\left.\mathrm{CDCl}_{3}\right): \delta(\mathrm{ppm}) 12.6,13.7,14.7,17.1,19.9,24.3,30.9,59.0,59.3,70.5$, and 105.0.

\subsubsection{Synthesis of monofunctional dendrimer containing long} chain alcohol undecan-1-ol (11)

1,3,5-triethynyl benzene (TEB) (30 mg, $0.2 \mathrm{mmol}$ ) and 11-Azido-undecan-1-ol ( $140.4 \mathrm{mg}, 0.66 \mathrm{mmol}$ ) were dissolved in $2 \mathrm{~mL}$ of THF, followed by addition of sodium ascorbate $(12 \mathrm{mg}, 0.06 \mathrm{mmol})$. An aqueous solution $(1 \mathrm{~mL})$ of $\mathrm{CuSO}_{4} \cdot 5 \mathrm{H}_{2} \mathrm{O}(7.5 \mathrm{mg}$ $0.03 \mathrm{mmol}$ ) was added dropwise to the solution which was left to stir overnight at $40^{\circ} \mathrm{C}$. THF was then evaporated, and the remaining solution was extracted with DCM $(3 \times 30 \mathrm{~mL})$, and dried over $\mathrm{MgSO}_{4}$. The solvent was evaporated, and the crude product was then purified by flash chromatography eluting the product with $4 \% \mathrm{MeOH}$ in DCM. The solvent was evaporated to yield the product as white solid (150 mg, 97\%). ${ }^{1} \mathrm{H}$ NMR ( $\left.400 \mathrm{MHz}, \mathrm{CDCl}_{3}\right): \delta(\mathrm{ppm}) 1.20-1.45\left(\mathrm{~m}, 42 \mathrm{H},-\mathrm{CH}_{2}-\right), 1.48-1.55\left(\mathrm{~m}, 6 \mathrm{H},-\mathrm{CH}_{2} \mathrm{CH}_{2} \mathrm{OH}\right)$, $1.90-2.02\left(\mathrm{~m}, 6 \mathrm{H},-\mathrm{CH}_{2} \mathrm{CH}_{2}\right.$-triazole), $3.63\left(\mathrm{t}, 6 \mathrm{H},-\mathrm{CH}_{2} \mathrm{CH}_{2} \mathrm{OH}\right), 4.43\left(\mathrm{t}, 6 \mathrm{H},-\mathrm{CH}_{2} \mathrm{CH}_{2}\right.$ triazole), 7.99 (s, 3H, ArH) and 8.32 (s, 3H, triazoleH); ${ }^{13} \mathrm{C}\left\{{ }^{1} \mathrm{H}\right\} \mathrm{NMR}\left(125 \mathrm{MHz}, \mathrm{CDCl}_{3}\right)$ : $\delta(\mathrm{ppm}) 25.6,26.3,28.8,29.2,29.3,29.4,30.2,32.8,50.5,62.9,120.2,122.1,131.8$ and 147.1. ESI-MS : $m / z 812.59\left([\mathrm{M}+\mathrm{Na}]^{+}\right), 790.60\left([\mathrm{M}+\mathrm{H}]^{+}\right)$.

\subsubsection{Synthesis of monofunctional dendrimer containing niacin (12)}

To a stirring solution of $\mathbf{1 1}$ ( $375 \mathrm{mg}, 0.475 \mathrm{mmol}$ ), 1-[3-(dimethylamino)propyl]-3ethylcarbodiimide methiodide (635.2 $\mathrm{mg}, 2.139 \mathrm{mmol}$ ), 4-(dimethylamino)pyridine ( $87 \mathrm{mg}, 0.713 \mathrm{mmol}$ ), pyridine $(1 \mathrm{~mL}$ ) in anhydrous $\mathrm{N}, \mathrm{N}$-dimethyl formamide (DMF) $(2 \mathrm{~mL})$, added nicotinic acid $(263.3 \mathrm{mg}, 2.139 \mathrm{mmol})$ and solution was stirred at room temperature for $24 \mathrm{~h}$. Water $(30 \mathrm{~mL})$ was added and extraction was done using dichloromethane $(3 \times 20 \mathrm{~mL})$. The combined organic extracts were then washed with water and brine, dried over sodium sulphate and concentrated under reduced pressure. The crude was then passed through a column of silica gel. The pure fractions of product were obtained using $7 \%$ methanol in DCM as an eluent. The fractions were then concentrated to afford the product as white solid. (340 mg, $65 \%)$. ${ }^{1} \mathrm{H}$ NMR $(400 \mathrm{MHz}$, $\left.\mathrm{CDCl}_{3}\right): \delta(\mathrm{ppm}) 1.20-1.45\left(\mathrm{~m}, 42 \mathrm{H},-\mathrm{CH}_{2}-\right), 1.70-1.76\left(\mathrm{~m}, 6 \mathrm{H},-\mathrm{CH}_{2} \mathrm{CH}_{2} \mathrm{OCO}-\right), 1.77-2.02$ (m, $6 \mathrm{H},-\mathrm{CH}_{2} \mathrm{CH}_{2}$-triazole), 4.33(t, $\left.6 \mathrm{H},-\mathrm{CH}_{2} \mathrm{CH}_{2} \mathrm{OCO}-\right), 4.43$ (t, $6 \mathrm{H},-\mathrm{CH}_{2} \mathrm{CH}_{2}$-triazole), 7.35-7.40 (m, 3H, ArH), $7.96(\mathrm{~s}, 3 \mathrm{H}, \mathrm{ArH}), 8.25-8.30(\mathrm{~m}, 6 \mathrm{H}, \mathrm{ArH}), 8.75-8.77(\mathrm{~m}, 3 \mathrm{H}$, ArH) and $9.22(\mathrm{~s}, 3 \mathrm{H}, \mathrm{ArH}) .{ }^{13} \mathrm{C}\left\{{ }^{1} \mathrm{H}\right\} \mathrm{NMR}\left(75 \mathrm{MHz}, \mathrm{CDCl}_{3}\right): \delta 25.6,26.5,28.6,29.0,29.2$ $29.3,29.4,30.3,50.5,65.6,120.1,122.1,123.3,131.8,137.0,147.1,150.9,153.3$ and 165.3. MALDI : $m / z 1111.54\left([\mathrm{M}+\mathrm{Li}]^{+}\right)$.

\subsubsection{Synthesis of monofunctional dendrimer containing $P E G_{750}$ (13)}

1,3,5-Triethynyl benzene (15 mg, $0.1 \mathrm{mmol})$ and $\mathrm{PEG}_{750}-\mathrm{N}_{3}(232.22 \mathrm{mg}$ $0.3 \mathrm{mmol}$ ) were dissolved in $2 \mathrm{~mL}$ of THF followed by addition of sodium ascorbate ( $6 \mathrm{mg}, 0.03 \mathrm{mmol}$ ). An aqueous solution ( $1 \mathrm{~mL}$ ) of $\mathrm{CuSO}_{4} .5 \mathrm{H}_{2} \mathrm{O}(3.5 \mathrm{mg}, 0.014 \mathrm{mmol})$ was added dropwise to the solution which was left to stir overnight at $40^{\circ} \mathrm{C}$. THF was then evaporated, and the remaining solution was extracted with DCM $(3 \times 30 \mathrm{~mL})$, and dried over $\mathrm{MgSO}_{4}$. The solvent was evaporated, and the crude product was then purified by flash chromatography eluting the product with $5 \% \mathrm{MeOH}$ in DCM. The solvent was evaporated to yield the product as transparent liquid $(200 \mathrm{mg}, 80.9 \%) .{ }^{1} \mathrm{H}$ $\operatorname{NMR}\left(400 \mathrm{MHz}, \mathrm{CDCl}_{3}\right): \delta(\mathrm{ppm}) 3.37\left(\mathrm{~s}, 9 \mathrm{H},-\mathrm{OCH} \mathrm{C}_{3}\right), 3.30-3.70(\mathrm{~m}, \mathrm{PEG} \mathbf{H}), 3.95(\mathrm{t}, 6 \mathrm{H}$, - $\mathrm{CH}_{2} \mathrm{CH}_{2}$-PEG), $4.63\left(\mathrm{t}, 6 \mathrm{H},-\mathrm{CH}_{2} \mathrm{CH}_{2}\right.$-triazole), 8.20(s, 3H, ArH) and 8.34(s, 3H,triazole H) $.{ }^{13} \mathrm{C}\left\{{ }^{1} \mathrm{H}\right\} \operatorname{NMR}\left(125 \mathrm{MHz}, \mathrm{CDCl}_{3}\right): \delta(\mathrm{ppm}) 25.6,29.6,50.5,53.4,58.9,67.9,69.5,70.6$ $71.9,72.6,114.5,122.2,128.8,129.5,130.9,131.9,161.0$ and 200.9 .

2.2.10. Synthesis of miktoarm carrier containing two $P E G_{750}$ units and niacin (15)

To a flame dried two neck round-bottom $100 \mathrm{~mL}$ flask, nicotinic acid ( $35 \mathrm{mg}$, $0.27 \mathrm{mmol})$, EDC (100 mg, $0.33 \mathrm{mmol})$, DMAP $(27 \mathrm{mg}, 0.22 \mathrm{mmol})$ and miktoarm containing two PEG molecules and benzylic alcohol $(400 \mathrm{mg}, 0.22 \mathrm{mmol})$ were added and dissolved in dry DMF $(5 \mathrm{~mL})$ under nitrogen atmosphere. The reaction mixture was stirred at room temperature overnight. Reaction completion was monitored with the help of TLC. The reaction mixture was diluted with water $(5 \mathrm{~mL})$ and extracted 3 times with dichloromethane. The organic layer was separated and washed with brine. It was then dried over anhydrous sodium sulphate and concentrated under reduced pressure. The compound was obtained as off white solid. (310 mg, 73\%) ${ }^{1} \mathrm{H}$ NMR(400 MHz, $\mathrm{CDCl}_{3}$ ): $\delta$ (ppm) 3.36 (s, -OCH $\mathrm{OCH}_{3}$ PE), 3.42-3.74 (m, PEG H), $3.86\left(\mathrm{t}, J=10 \mathrm{~Hz}\right.$, PEG H), $4.53\left(\mathrm{t}, J=10 \mathrm{~Hz}\right.$, PEG-CH $\left.\mathbf{C H}_{2}\right), 5.16$ $(\mathrm{s}, 4 \mathrm{H}), 5.29\left(\mathrm{~d}, J=6.4 \mathrm{~Hz}, 2 \mathrm{H},-\mathrm{OCH} \mathrm{C}_{2}\right), 6.58-6.70(\mathrm{~m}, 3 \mathrm{H}, \mathrm{ArH}), 7.40(\mathrm{t}, J=6.2 \mathrm{~Hz}$, $1 \mathrm{H}, \mathrm{ArH}$ ), 7.783 (s, $2 \mathrm{H}$, triazole), 8.32 (d, $J=16 \mathrm{~Hz}, 2 \mathrm{H}, \mathrm{ArH}), 8.76(\mathrm{~d}, 6.4 \mathrm{~Hz}, 1 \mathrm{H}$, $\mathrm{ArH}$ ) and $9.23(\mathrm{~s}, 1 \mathrm{H}) .{ }^{13} \mathrm{C}\left\{{ }^{1} \mathrm{H}\right\} \mathrm{NMR}\left(100 \mathrm{MHz}, \mathrm{CDCl}_{3}\right): \delta(\mathrm{ppm}) 50.3,59.0,62.0,66.7$, 69.3, 70.4, 70.5.71.8, 101.6, 107.1, 123.3, 124.1, 137.2, 137.8, 143.4, 151.0, 153.5, 159.6 and 164.9

\subsection{Cell cultures}

Murine microglia (N9) were cultured in Iscove's modified Dulbecco's medium (IMDM; Gibco \# 12440) supplemented with $5 \%$ (v/v) fetal bovine serum (FBS; Gibco) and $1 \%(\mathrm{v} / \mathrm{v})$ penicillin/streptomycin (Gibco). Human HepG2 hepatocytes were cultured in high glucose Dulbecco's Modified Eagle Medium (DMEM; Gibco \#11995) supplemented with $5 \%(\mathrm{v} / \mathrm{v})$ fetal bovine serum (FBS; Gibco) and $1 \%(\mathrm{v} / \mathrm{v})$ penicillin/ streptomycin (Gibco).

\subsection{Nitric oxide production}

Release of nitric oxide (NO) from microglial cultures was measured using the Griess reagent (Sigma, G-4410). Cells seeded at a density of $2 \times 10^{5}$ in 24 -well culture plates (Sarstedt) were treated with the drugs and the polymers for $24 \mathrm{~h}$ in $1 \%$ FBS containing media. At the end of treatments, supernatants $(50 \mu \mathrm{L})$ were collected and incubated with the Griess reagent $(50 \mu \mathrm{L})$ for $15 \mathrm{~min}$, after which the absorbance $(540 \mathrm{~nm})$ was measured with a spectrophotometer. A standard curve with different concentrations of nitrite was created.

\subsection{Measurement of biocompatibility by the MTT reduction assay}

N9 microglia were seeded in 24 -well plates $\left(5 \times 10^{4}\right.$ cells/well) and cultured for $24 \mathrm{~h}$ in 5\% FBS containing culture media. Cells were treated with the drugs and the polymers for 24 and $48 \mathrm{~h}$ in $1 \%$ FBS containing culture media. The vehicle treatment consisted of $0.5 \%$ DMSO. The polymers $\mathbf{1 5}$ and $\mathbf{1 2}$ were added at a concentration of $50 \mu \mathrm{m}$ (calculated to account for the concentration of niacin). 4,10 and $\mathbf{7}$ were added at a concentration of $1 \mu \mathrm{m}$ (accounting for the final concentration of BODIPY). MTT (Thiazolyl blue tetrazolium bromide) assay was performed to assess the mitochondrial metabolic activity. MTT reagent (M2128, Sigma) was dissolved in phosphate buffered saline (PBS) $(5 \mathrm{mg} / \mathrm{mL}$ ). Following treatments ( 24 or $48 \mathrm{~h}$ ), old media was removed from culture plates. Cells were incubated in fresh media $(1 \%$ FBS) containing MTT $(0.5 \mathrm{mg} / \mathrm{mL})$ for $30 \mathrm{~min}$ at $37^{\circ} \mathrm{C}$. Subsequently, cells were lysed with $500 \mu \mathrm{L}$ of dimethyl sulfoxide (Sigma, 154938). Absorbance was measured at $595 \mathrm{~nm}$ using a Benchmark microplate reader (Bio-Rad, Mississauga, ON, Canada). All measurements were performed in quadruplicates.

\subsection{Confocal microscopy}

Images were acquired with a Zeiss LSM 510 NLO inverted confocal microscope using a Plan Achromat 63X/1.4 Oil DIC objective. Microglial cells were seeded at a density of $1.5 \times 10^{4}$ cells/well on confocal chamber slides (Lab-Tek, Nalge Nunc International, Rochester, NY, USA) and cultured for $24 \mathrm{~h}$ prior to experiments. LDs were stained with the neutral lipid staining fluorophore Bodipy 493/503 (4,4difluoro-1,3,5,7,8-pentamethyl-4- bora-3a,4a-diaza-s-indacene) for $10 \mathrm{~min}(20 \mu \mathrm{M})$. The polymers 4, 10 and $\mathbf{7}$ were added to living microglia at a final concentration of $1 \mu \mathrm{m}$ and imaged after $2 \mathrm{~min}$. Images of LDs and fluorescent polymers were acquired at a resolution of $1024 \times 1024$ using the Argon $488 \mathrm{~nm}(4 \%)$ and the HeNe $543 \mathrm{~nm}$ (100\%) excitation lasers, respectively. For each Z-stack, a total of $10 \mathrm{Z}$-slices were acquired using a scaling of $0.07 \times 0.07 \times 0.30 \mu \mathrm{m}(\mathrm{x}, \mathrm{y}, \mathrm{z})$.

\subsection{Flow cytometry}

N9 microglial cells and HepG2 hepatocytes were seeded at a density of $3 \times 10^{5}$ cells and $1 \times 10^{6}$, respectively, in 12 well plates (Sarstedt). Cells were treated with fluorescent polymers $\mathbf{4 , 1 0}$ and $\mathbf{7}$ for $1,6,24$ and $48 \mathrm{~h}$ in $1 \%$ FBS containing media. The final concentration of the polymers in the culture was $1 \mu \mathrm{m}$ (accounting for the final concentration of BODIPY). Following treatments, plates were washed with PBS, followed by a mild acidic (PBS at pH 5.5) wash. Cells were removed from plates mechanically by scraping and kept in $0.5 \%$ BSA containing PBS until analysis by flow cytometry. Samples were analyzed using a Becton Dickinson FACSscan flow cytometer. The fluorescence of the polymers was measured using the 544/590 (excitation/emission) setting and was expressed as mean fluorescence intensity (MFI). 


\subsection{Statistics}

Statistical analysis was performed using Systat (version 10.2). Comparisons between multiple groups were done using $t$-tests followed by a Bonferroni correction. All data are presented as group means \pm SEM. $p<0.05$ was considered significant.

\section{Results and discussion}

\subsection{Synthesis of nanocarriers}

The development of a bifunctional nanocarrier to target LD was based on designing an orthogonal molecular system that would allow covalent linking of two different functional units using $\mathrm{Cu}(\mathrm{I})$ catalyzed alkyne-azide "click" chemistry [7-10]. Such a building block contains an azide group and two acetylenes protected with trimethylsilyl and triisopropyl groups respectively [34]. Upon selectively deprotecting the trimethylsilyl-acetylene, it was clicked with 11-azido-undecan-1-ol to give compound 1 (Scheme 1) [31]. The latter was covalently linked to the 1,3,5-triethynylbenzene core using the "click" reaction, and the triisopropylsilylacetylene was then deprotected (2, Scheme 1). The primary alcohol on this compound was employed for the attachment of the drug niacin using a simple esterification reaction. It should be noted that it was essential to remove the bulky triisopropyl groups from the acetylene first, since it was not possible to carry out the subsequent esterification reaction cleanly in their presence. The free acetylene groups on compound $\mathbf{3}$ were then clicked with azide-functionalized BODIPY dye using copper sulphate and sodium ascorbate in a THF/water mixture, to give the desired bifunctional dendrimer 4 (Scheme 1) [31]. The reaction was monitored easily using ${ }^{1} \mathrm{H}$ NMR

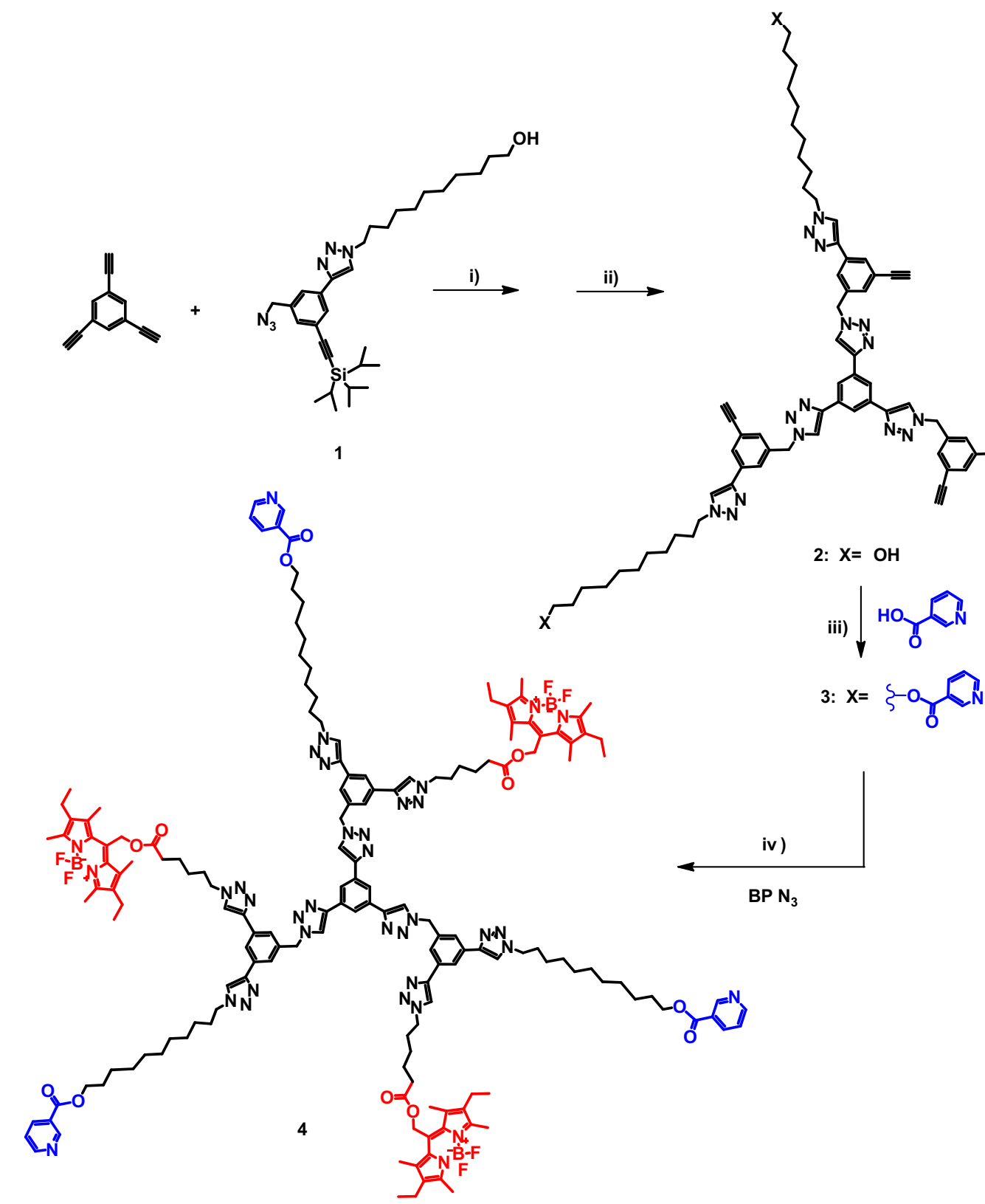

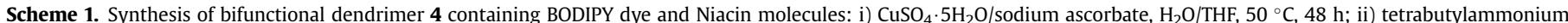

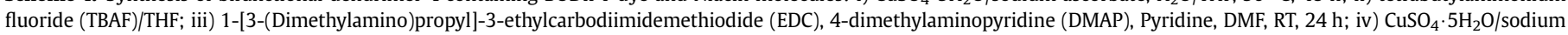
ascorbate, $\mathrm{H}_{2} \mathrm{O} / \mathrm{THF}, \mathrm{RT}$, Overnight $(\mathrm{O} / \mathrm{N})$. 
<smiles>[CH2+]C#Cc1ccc(-c2cn(C(C)(C)CO)nn2)cc1</smiles>

5

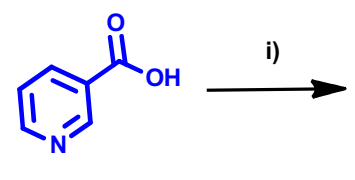

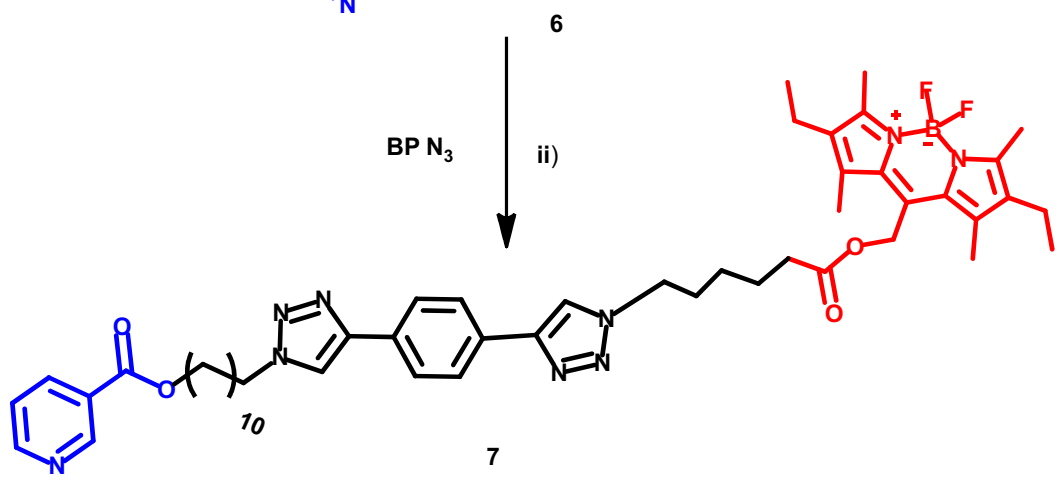

Scheme 2. Synthesis of linear analog 7 containing covalently linked BP dye and Niacin: i) EDC, DMAP, Pyridine, DMF, RT, 24 h.; ii) $\mathrm{CuSO}_{4} .5 \mathrm{H}_{2} \mathrm{O}$, Sodium Ascorbate, $\mathrm{THF} / \mathrm{H}_{2} \mathrm{O}$, $\mathrm{O} / \mathrm{N}, \mathrm{RT}$.

which showed the disappearance of acetylene peak at $3.11 \mathrm{ppm}$ and the appearance of BODIPY protons. It is important to follow this sequence of reactions since if BODIPY is clicked first, followed by esterification with niacin, it leads to very poor yield of the product. Dendrimer size could be an important variable in designing dendrimer based conjugates depending on their intended application [35]. For instance, smaller generations such as in $\mathbf{4}$ which is estimated to be about 3-4 $\mathrm{nm}$ in size [36], with tailored active sites, are in fact desirable for nanodelivery carriers targeting different intracellular locations. It should also be noted that the copper(I) compounds used in the "click" reactions are in catalytic amounts, and the "clicked" products contain nonmeasureable amount of copper [37]. It is also ascertained by the biocompatibility of the nanoconjugates reported here.

A linear model of the bifunctional dendrimer $\mathbf{4}$ was synthesized starting from (4-ethynyl-phenylethynyl)-triisopropyl-silane, on which two click reactions were carried out in sequence. 11-Azidoundecan-1-ol was first clicked using the free acetylene arm of (4-ethynyl-phenylethynyl)-triisopropyl-silane to give compound $\mathbf{5}$ (Scheme 2). The second acetylenic arm of this molecule was then deprotected, and the drug niacin was covalently linked through the primary alcohol using the esterification reaction ( 6 , Scheme 2$)$. The<smiles>C#Cc1cc(CO)cc(-c2cn(CC(C)(C)OCCOCCOC)nn2)c1</smiles>

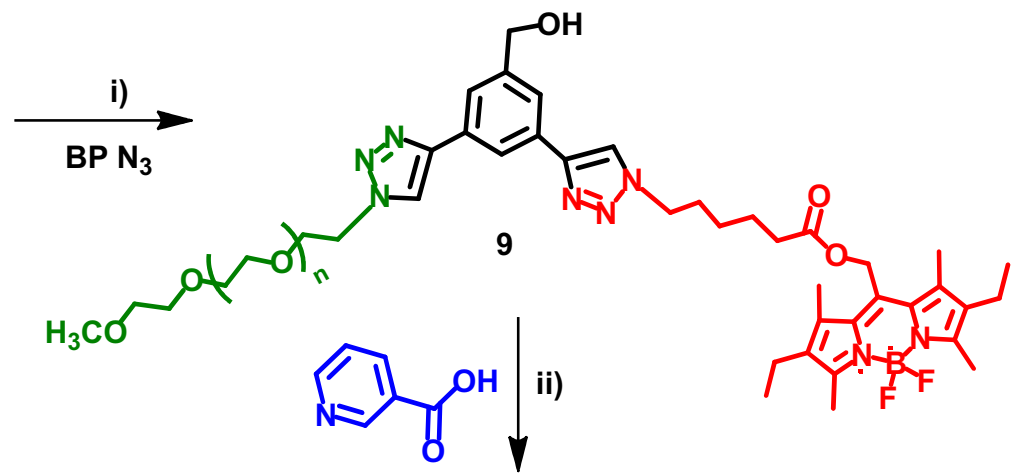<smiles>CCc1c(C)c(COC(=O)CCCCCn2cc(-c3cc(COC(=O)c4cccnc4)cc(-c4cn(CC(C)(C)CCC(C)(C)OCCCOC)nn4)c3)nn2)c2c(C)c(CC)n(C(F)(F)F)c2c1CC</smiles> 
free acetylene arm was subsequently used to click the BODIPY dye molecule to get the desired compound $\mathbf{7}$ (Scheme 2). The reaction could be once again easily monitored using ${ }^{1} \mathrm{H}$ NMR.

To examine the role of the carrier structure on the internalization process, we synthesized a trifunctional molecular unit containing BODIPY dye, niacin, and polyethylene glycol (PEG) 750 covalently linked to the central core. This miktoarm carrier is structurally different from the dendrimer. The core molecule containing PEG, an unprotected acetylene and benzylic alcohol (8, Scheme 3) was first prepared using a literature procedure [32]. The free acetylene in compound $\mathbf{8}$ was then reacted with BODIPY-azide using copper sulfate pentahydrate and sodium ascorbate as catalysts. For this reaction to go to completion, the use of an extremely concentrated solution was necessary. This reaction can also be monitored by ${ }^{1} \mathrm{H}$ NMR in which the loss of the acetylene peak at $3.11 \mathrm{ppm}$, and the appearance of BODIPY protons provided evidence for the completion of the "click" reaction (9, Scheme 3). Finally, nicotinic acid was linked to 9 by esterification using EDC/DMAP to yield the desired compound $\mathbf{1 0}$ (Scheme 3). The conjugation of nicotinic acid in $\mathbf{1 0}$ was evidenced by a shift in the ${ }^{1} \mathrm{H}$ NMR of the aryl ring's benzylic methylene from $4.77 \mathrm{ppm}$ to $5.52 \mathrm{ppm}$, as well as the absence of any carboxylic acid peaks.

We also synthesized a monofunctional dendrimer containing three drug molecules attached to it. For that purpose, we started with the trifunctional core with three free acetylene arms available for click reaction, and first clicked this core molecule with 11-azidoundecan-1-ol to obtain $\mathbf{1 1}$ with three terminal hydroxyl groups. Niacin was then coupled with these primary alcohol groups using esterification reaction (12, Scheme 4$)$.

Similarly, we synthesized dendrimer containing only the polyethylene glycol arms (13), and a miktoarm carrier containing two PEG chains and a niacin molecule (15). Azide functionalized PEG-750 was first synthesized using a literature procedure [38], and it was then clicked with 1,3,5-triethynylbenzene core using conditions described earlier to give compound 13 (Scheme 4). Again the disappearance of acetylene peak and appearance of PEG

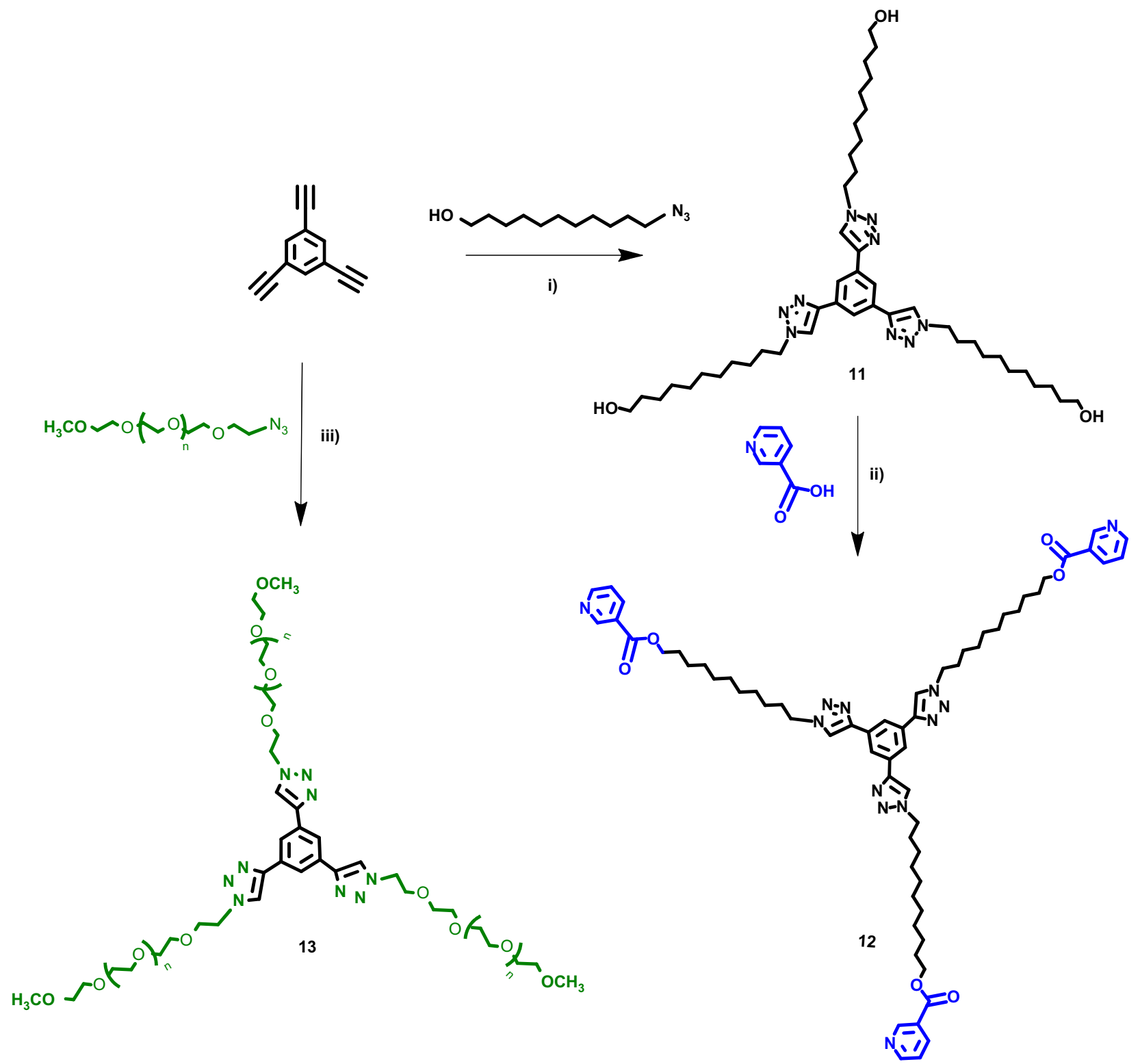

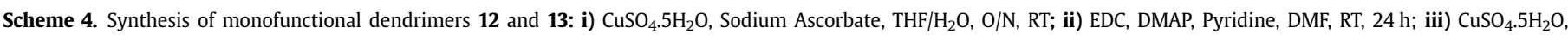
Sodium Ascorbate, $\mathrm{THF} / \mathrm{H}_{2} \mathrm{O}, \mathrm{O} / \mathrm{N}$, RT. 

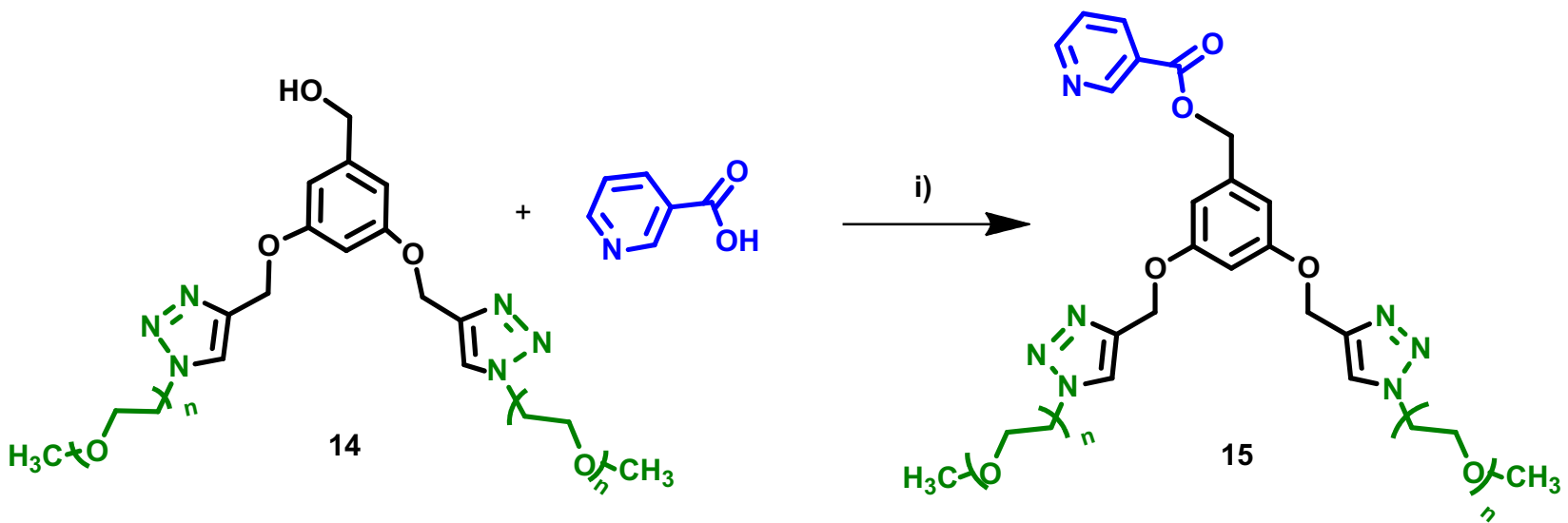

Scheme 5. Synthesis of 15: i) EDC, DMAP, DMF, O/N, RT.

protons in ${ }^{1} \mathrm{H}$ NMR was used to confirm the completion of the reaction. For the synthesis of the miktoarm carrier with two PEG arms and one niacin molecule, we started with miktoarm core molecule with two PEG arms and a benzylic alcohol which was synthesized using a literature procedure [32]. The benzylic hydroxyl group of this core molecule was used to attach the drug molecule using the esterification reaction resulting in compound $\mathbf{1 5}$ (Scheme 5).

\subsection{Biological studies}

We subsequently examined the uptake of the fluorescent carriers $\mathbf{4}, \mathbf{7}$ and $\mathbf{1 0}$ by fluorescence activated cell sorting (FACS) analysis. The uptake was monitored in microglia and in hepatocytes. All carriers were taken up by the cells in a time-dependent manner (Fig. 1). The uptake of all three compounds seemed to take place at a faster rate in hepatocytes (Fig. 1b) than in microglia
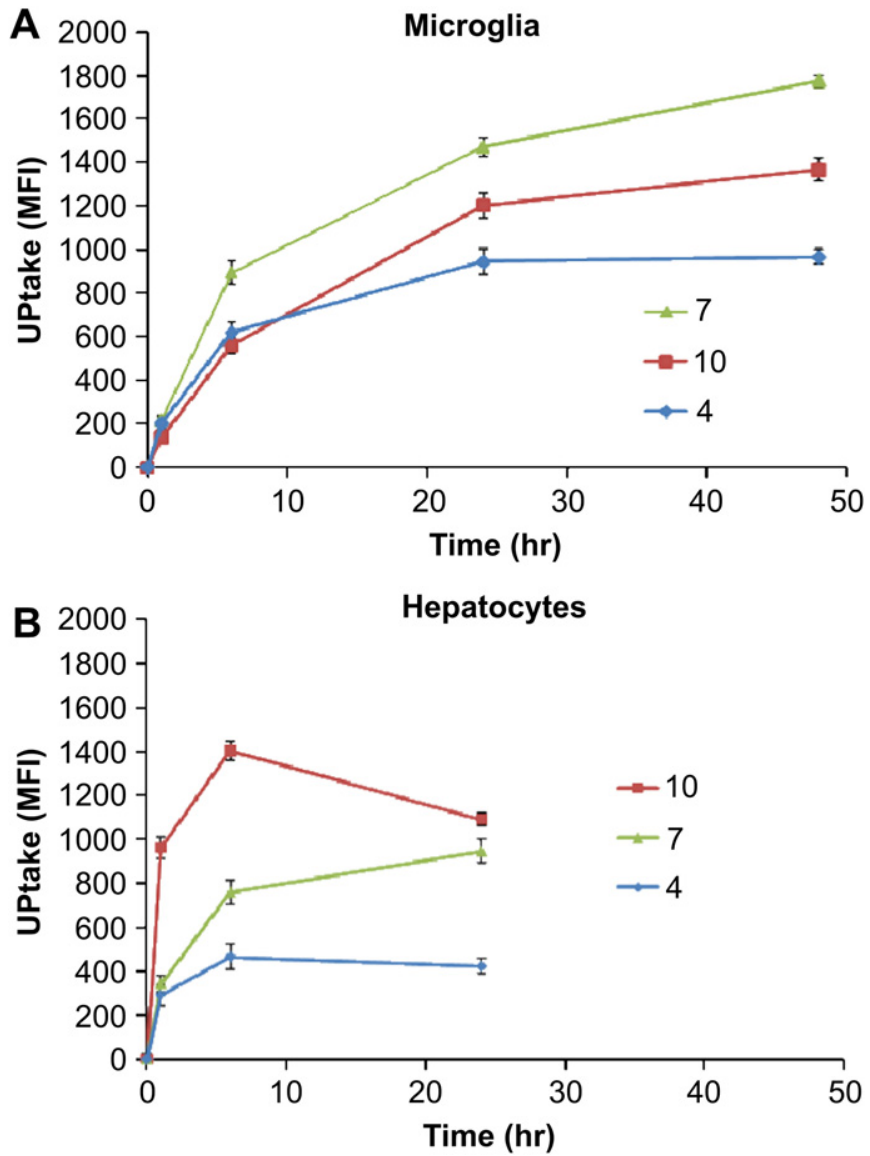

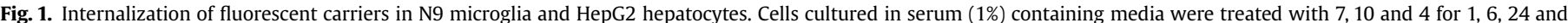

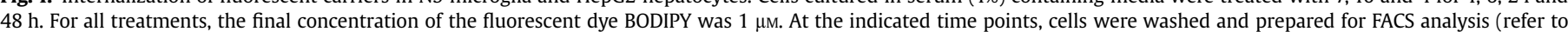

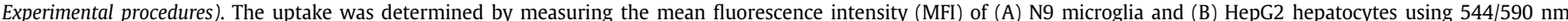

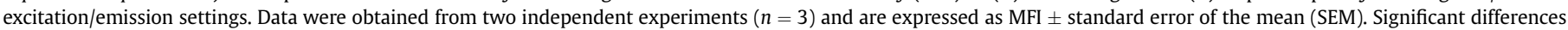
and $p$ values are discussed in Results and discussion. 


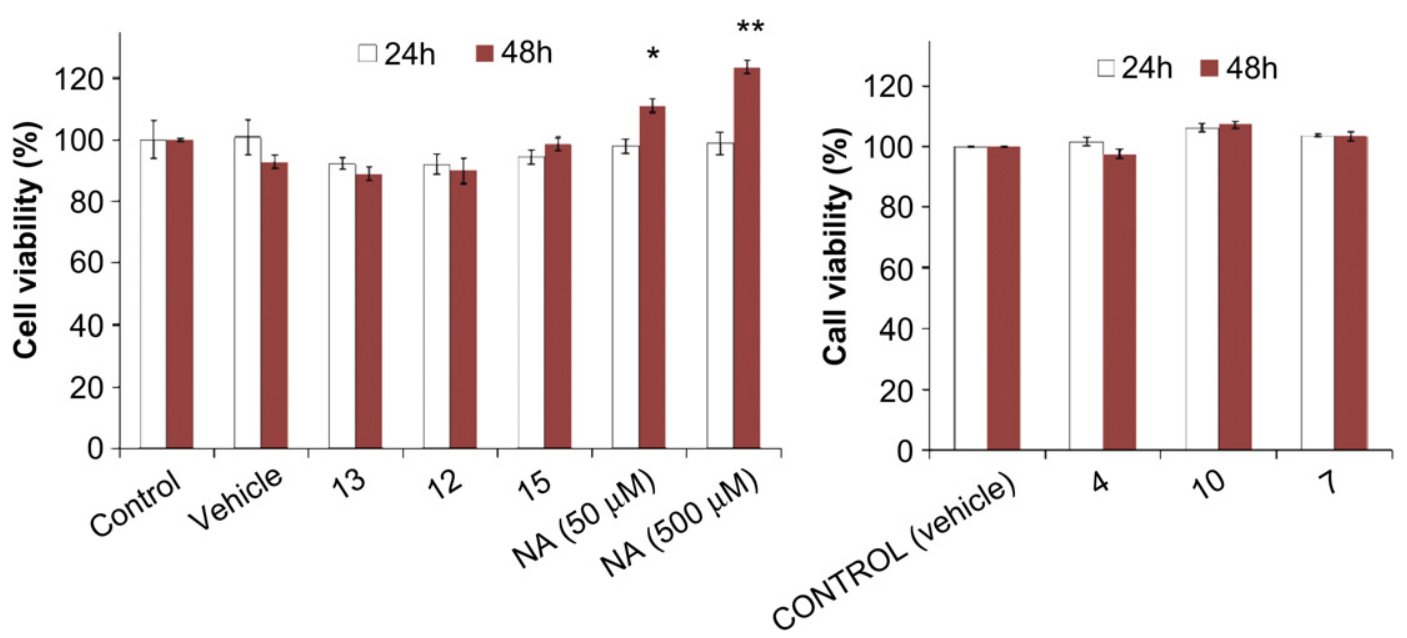

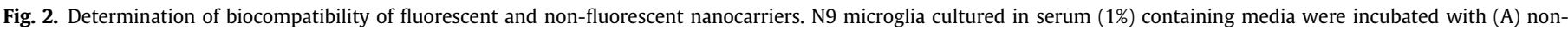

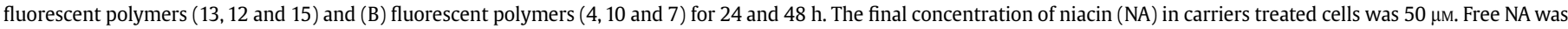

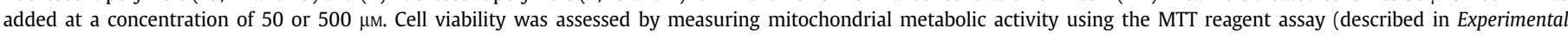

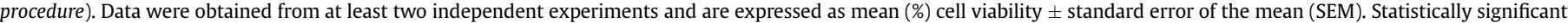
differences are indicated by ${ }^{*} p<0.05$ and ${ }^{* *} p<0.005$.

(Fig. 1a). In fact, the equilibrium in their uptake was reached earlier (after $6 \mathrm{~h}$ ) in the hepatocytes than in microglia (not before $24 \mathrm{~h}$ ). The maximal uptake value for $\mathbf{4}$ in both microglia and hepatocytes (966 \pm 30 and $467 \pm 42 \mathrm{MFI}$ ) was smaller than the maximal value for $10(1366 \pm 52$ and $1403 \pm 56 \mathrm{MFI}, p<0.05)$ and $7(1773 \pm 36$ and $947 \pm 36)$ MFI respectively, $p<0.05)$. In order to demonstrate that this was not due to the intrinsic fluorescence properties of $\mathbf{4}$, we measured the relative fluorescence intensity (RFI) of the 4, 7 and $\mathbf{1 0}$ in pure dimethyl sulfoxide using a spectrofluorometer (Fig. S1). The relative fluorescence intensity (shown as absolute values) of 4 was higher at all concentrations examined (1,5 and $20 \mu \mathrm{m})$ than that of 10, which in turn had a greater fluorescence intensity than $\mathbf{7}$.

To gain an insight into the biocompatibility of the nanocarriers, microglial cells were treated with $\mathbf{1 2 , 1 3}$ and $\mathbf{1 5}(50 \mu \mathrm{m})$ for either 24 or $48 \mathrm{~h}$ (Fig. 2A). We selected microglia because these cells are critically involved in the environmental surveillance" and they promptly respond to an insult or exposure to nanoparticles [39,40]. Moreover, they release both cytokines and trophic factors depending of the stimulus). We have previously shown that even extremely small amounts of nanoparticles in the central nervous system (CNS) cause an activation of microglia and astrocytes in mice [41,42]. None of the carriers used in the present studies markedly changed microglia morphology or enhanced their activity. Similarly, there was no significant decrease in cell viability when compared with the vehicle treatment after either 24 or $48 \mathrm{~h}$, as determined by measurements of the mitochondrial metabolic activity. In addition, fluorescent nanocarriers were also not cytotoxic (Fig. 2B); Treatment of microglia with niacin $(50 \mu \mathrm{M})$ significantly increased mitochondrial metabolic activity after $48 \mathrm{~h}(11 \%, p<0.05)$ confirming that free niacin does not cause functional impairment of these cells.

To examine the physiological response of microglia to niacin nanodelivery systems, cells were challenged with bacterial endotoxin lipopolysaccharide (LPS), a well-established inducer of nitric oxide (NO) release [43]. NO was measured both in non-challenged and LPS-exposed cells and the extent of NO induced by LPS served as a positive control for microglia activation. Excessive microglial activation (reactive microgliosis) may be responsible for neurotoxicity and is involved in the progression of neurodegenerative

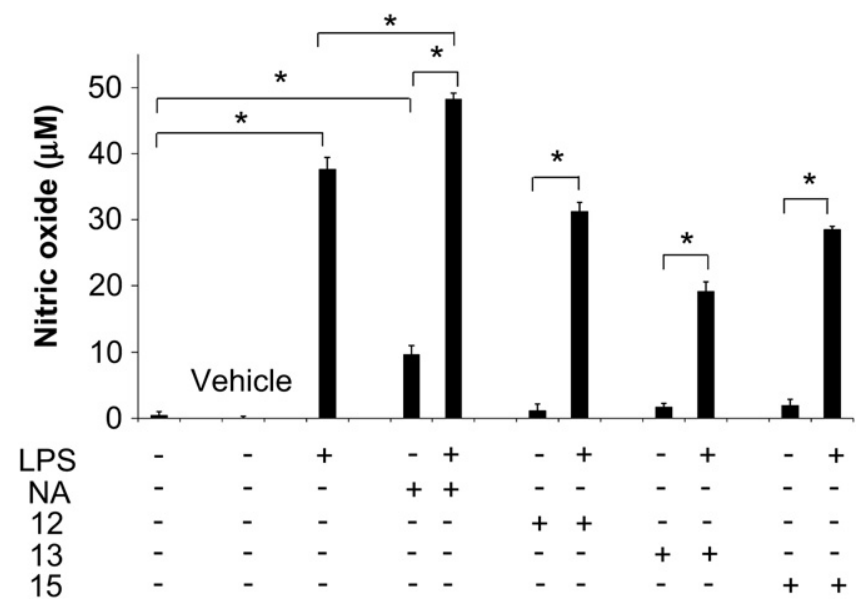

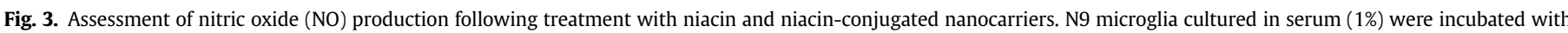

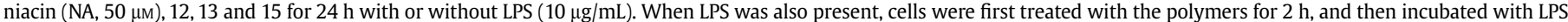

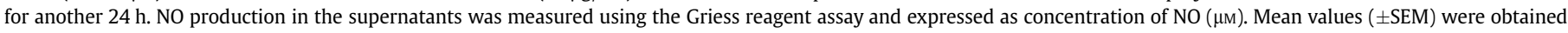
from triplicate analysis and from at least two independent experiments. Statistically different values are indicated by ${ }^{*} p<0.005$. 


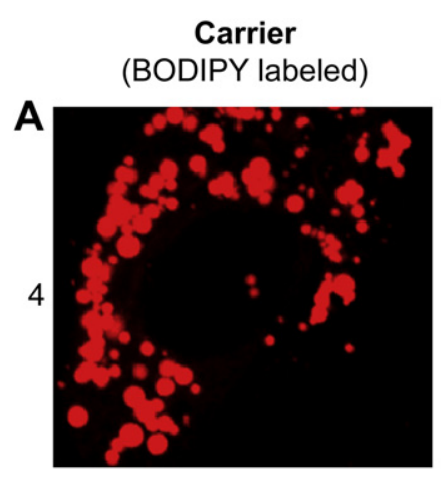

Lipid droplets
(Bodipy 493/503)
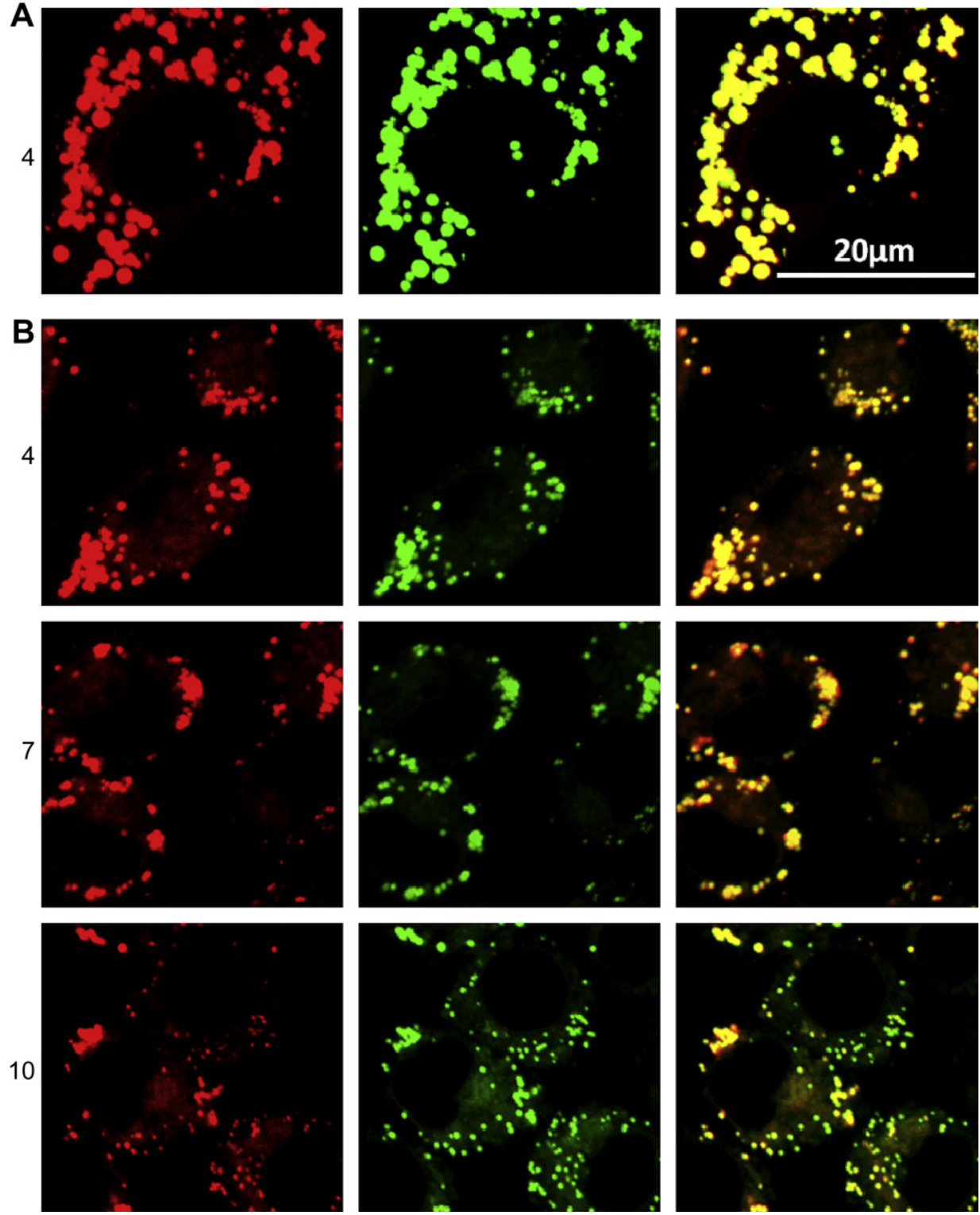

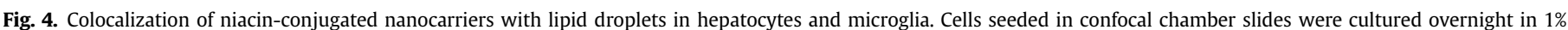

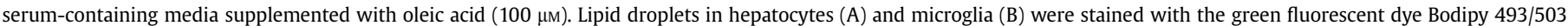

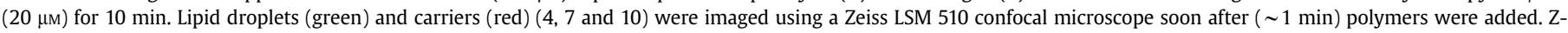

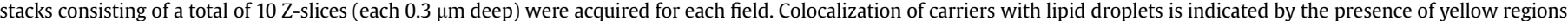
resulting from the overlap between the signal in the green and red channels. Scale bar $=20 \mu \mathrm{m}$.

diseases [44]. Importantly, microglia may express the inducible nitric oxide synthase (iNOS), an enzyme critical for NO production during inflammation. The production of NO following niacin $(50 \mu \mathrm{M})$ treatment was significantly increased $(9.7 \mu \mathrm{M}, p<0.005)$, as compared to vehicle-treated $(0.5 \%$ DMSO) control $(0.4 \mu \mathrm{M})$. There seemed to be an additive $(p<0.005)$ effect when niacin and LPS were present together in the cell culture medium. The combination resulted in a large production of $\mathrm{NO}(48.3 \mu \mathrm{M})$ significantly higher than NO produced by LPS alone $(37.7 \mu \mathrm{m}, p<0.005)$. The carriers alone $(50 \mu \mathrm{m})$ did not stimulate NO production in cells when compared to the cells treated with the vehicle $(0.5 \%$ DMSO v/v). Production of NO in cells treated with both the carriers and LPS appeared to be lower than in the cells exposed to LPS alone, suggesting that the carriers by themselves could partly prevent LPS-induced NO release (Fig. 3).

In order to assess the efficacy of the niacin-conjugated nanocarriers as a lipid droplet targeting drug delivery system, we examined their colocalization with these organelles by confocal microscopy. The intracellular LDs were stained with the fluorescent dye Bodipy 493/503 (green), which selectively stains neutral lipids. The carriers, labelled with a different Bodipy (red), were added separately following the staining of LDs. Within seconds, the fluorescent carriers were detected in the cytosol and within cytoplasmic LDs (Fig. 4). The colocalization of the carrier with the lipid droplets was indicated by the droplets appearing yellow instead of the green observed in the absence of the carrier. Carriers $\mathbf{4}$ and $\mathbf{7}$ 
seemed to be entirely colocalized with the LDs. The colocalization of 4 with LDs is shown in hepatocyte (Fig. 4A) and microglia LDs (Fig. 4B). The trifunctional polymer 10, however, partially colocalized with the LDs (Fig. 4B). The presence of polyethylene glycol (PEG) in structure $\mathbf{1 0}$ (but not in $\mathbf{4}$ or $\mathbf{7}$ ) could reduce colocalization with highly lipophilic organelles, i.e. lipid droplets. Molecular modeling studies are necessary to examine the possibility that conformational differences between the structures $\mathbf{4 , 7}$ and $\mathbf{1 0}$ could also contribute to the differences in their co-localization with LDs and to their modes of internalization.

\section{Conclusions}

In summary, results from this study show localization of niacinconjugated carriers to lipid droplets (LDs), a new organelle considered for subcellular targeting by nanostructures. Herein, we aimed at delivering niacin to LDs by means of dendrimeric and other polymeric structures, synthesized using "click" chemistry, in order to inhibit the activity of LD-localized enzyme, DGAT2, which is a critical enzyme in triglyceride biosynthesis. Such an approach will possibly give rise to the emergence of new strategies in nanomedicine in the treatment of diseases characterized by excessive accumulation of triglycerides (i.e LDs), such as obesity, hepatic steatosis and atherosclerosis [26,45]. The versatility of the click chemistry approach described here uniquely enables the design and construction of a variety of tunable nanomaterials with orthogonal functionalities, to target drugs, fluorophores or sensors to other organelles.

\section{Acknowledgement}

AK and DM thank NSERC of Canada and Canadian Institutes for Healt Research (CIHR) for financial assistance. We are also thankful to Angela O. Choi and Noura Abdulhafdh for assistance in nitric oxide release and FACS analysis.

\section{Appendix}

Figures with essential colour discrimination. Certain figures in this article Figs. 1,2 and 4 and Scheme 1-5 are difficult to interpret in black and white. The full colour images can be found in the online version, at doi:10.1016/j.biomaterials.2010.10.025.

\section{Appendix. Supplementary information}

Supplementary information associated with this article can be found in the on-line version, at doi:10.1016/j.biomaterials.2010.10. 025 .

\section{References}

[1] Haag R, Kratz F. Polymer therapeutics: concepts and applications. Angew Chem Int Ed Engl 2006;45(8):1198-215.

[2] Rudin M, Weissleder R. Molecular imaging in drug discovery and development. Nat Rev Drug Discov 2003;2(2):123-31.

[3] Maeda H, Seymour LW, Miyamoto Y. Conjugates of anticancer agents and polymers: advantages of macromolecular therapeutics in vivo. Bioconjug Chem 1992;3(5):351-62.

[4] Lee CC, MacKay JA, Frechet JM, Szoka FC. Designing dendrimers for biological applications. Nat Biotechnol 2005;23(12):1517-26.

[5] Bayele HK, Ramaswamy C, Wilderspin AF, Srai KS, Toth I, Florence AT. Protein transduction by lipidic peptide dendrimers. J Pharm Sci 2006;95 (6):1227-37.

[6] Astruc D, Boisselier E, Ornelas C. Dendrimers designed for functions: from physical, photophysical, and supramolecular properties to applications in sensing, catalysis, molecular electronics, photonics, and nanomedicine. Chem Rev 2010;110(4):1857-959.

[7] Franc G, Kakkar A. Dendrimer design using $\mathrm{Cu}(\mathrm{I})$-catalyzed alkyne-azide "click-chemistry". Chem Commun 2008;42:5267-76.
[8] Franc G, Kakkar AK. Diels-Alder "click" chemistry in designing dendritic macromolecules. Chem Eur J 2009;15(23):5630-9.

[9] Franc G, Kakkar AK. Click" methodologies: efficient, simple and greener routes to design dendrimers. Chem Soc Rev 2010;39(5):1536-44.

[10] Kolb HC, Finn MG, Sharpless KB. Click chemistry: diverse chemical function from a few good reactions. Angew Chem Int Ed Engl 2001;40(11): 2004-21.

[11] DeForest CA, Polizzotti BD, Anseth KS. Sequential click reactions for synthesizing and patterning three-dimensional cell microenvironments. Nat Mater 2009;8:659-64.

[12] Rajendran L, Knolker HJ, Simons K. Subcellular targeting strategies for drug design and delivery. Nat Rev Drug Discov 2010;9(1):29-42.

[13] Savic R, Luo L, Eisenberg A, Maysinger D. Micellar nanocontainers distribute to defined cytoplasmic organelles. Science 2003;300(5619):615-8.

[14] Boddapati SV, D'Souza GG, Erdogan S, Torchilin VP, Weissig V. Organelle-targeted nanocarriers: specific delivery of liposomal ceramide to mitochondria enhances its cytotoxicity in vitro and in vivo. Nano Lett $2008 ; 8(8)$ : 2559-63.

[15] Said HM, Nabokina SM, Balamurugan K, Mohammed ZM, Urbina C, Kashyap ML. Mechanism of nicotinic acid transport in human liver cells: experiments with HepG2 cells and primary hepatocytes. Am J Physiol, Cell Physiol 2007;293(6):C1773-8.

[16] Listenberger LL, Brown DA. Fluorescent detection of lipid droplets and associated proteins. Curr Protoc Cell Biol; 2007 [Chapter 24], Unit 242.

[17] McKenney J. New perspectives on the use of niacin in the treatment of lipid disorders. Arch Intern Med 2004;164(7):697-705.

[18] McKenney J. Niacin for dyslipidemia: considerations in product selection. Am J Health Syst Pharm 2003;60(10):995-1005.

[19] Kamanna VS, Kashyap ML. Mechanism of action of niacin on lipoprotein metabolism. Curr Atheroscler Rep 2000;2(1):36-46.

[20] Brown BG, Zhao XQ. Nicotinic acid, alone and in combinations, for reduction of cardiovascular risk. Am J Cardiol 2008;101(8A):58B-62B.

[21] Benyo Z, Gille A, Kero J, Csiky M, Suchankova MC, Nusing RM, et al. GPR109A (PUMA-G/HM74A) mediates nicotinic acid-induced flushing. J Clin Invest 2005; 115(12):3634-40

[22] Pieper JA. Understanding niacin formulations. Am J Manag Care 2002;8(12 Suppl):S308-14.

[23] Kamanna VS, Ganji SH, Kashyap ML. The mechanism and mitigation of niacininduced flushing. Int J Clin Pract 2009;63(9):1369-77.

[24] Penberthy WT. Nicotinic acid-mediated activation of both membrane and nuclear receptors towards therapeutic glucocorticoid mimetics for treating multiple sclerosis. PPAR Res 2009;2009:853707.

[25] Ganji SH, Tavintharan S, Zhu D, Xing Y, Kamanna VS, Kashyap ML. Niacin noncompetitively inhibits DGAT2 but not DGAT1 activity in HepG2 cells. J Lipid Res 2004;45(10):1835-45.

[26] Martin S, Parton RG. Lipid droplets: a unified view of a dynamic organelle. Nat Rev Mol Cell Biol 2006;7(5):373-8.

[27] Stone SJ, Levin MC, Zhou P, Han J, Walther TC, Farese Jr RV. The endoplasmic reticulum enzyme DGAT2 is found in mitochondria-associated membranes and has a mitochondrial targeting signal that promotes its association with mitochondria. J Biol Chem 2009;284(8):5352-61.

[28] Kuerschner L, Moessinger C, Thiele C. Imaging of lipid biosynthesis: how a neutral lipid enters lipid droplets. Traffic 2008;9(3):338-52.

29] Farese Jr RV, Walther TC. Lipid droplets finally get a little R-E-S-P-E-C-T. Cell 2009;139(5):855-60.

[30] Weber E, Hecker M, Koepp E, Orlia W, Czugler M, Csöregh I. New trigona lattice hosts: stoicheiometric crystal inclusions of laterally trisubstituted benzenes-X-ray crystal structure of 1,3,5-tris-(4-carboxyphenyl)benzene-dimethylformamide. J Chem Soc, Perkin Trans. 1988;2:1251-8.

[31] Hourani R, Jain M, Maysinger D, Kakkar A. Multi-tasking with single scaffold dendrimers for targeting sub-cellular microenvironments. Chem Eur J 2010 16(21):6164-8.

[32] Khanna K, Varshney S, Kakkar A. Designing miktoarm polymers using a combination of "click" reactions in sequence with ring opening polymerization. Macromolecules 2010;43:5688-98.

[33] Soliman GM, Sharma R, Choi AO, Varshney SK, Winnik FM, Kakkar AK, et al. Tailoring the efficacy of nimodipine drug delivery using nanocarriers based on $\mathrm{A}_{2} \mathrm{~B}$ miktoarm star polymers. Biomaterials 2010;31:8382-92.

[34] Hourani R, Sharma A, Kakkar A. Designing dendritic frameworks using versatile building blocks suitable for Cu'catalyzed alkyne azide "click" chemistry. Tett Lett 2010;51(29):3792-5.

35] Wängler C, Moldenhauer G, Eisenhut M, Haberkorn U, Mier W. Antibodydendrimer conjugates: the number, not the size of the dendrimers, determines the immunoreactivity. Bioconjug Chem 2008;19:813-20.

[36] Hourani R, Kakkar AK, Whitehead MA. 3,5-Dihydroxybenzylalcohol based dendrimers: structure evaluation and molecular encapsulation in generations 1-5. J Mater Chem 2005;15:2106-13.

[37] Hein CD, Liu X-M, Wang D. Click chemistry, a powerful tool for pharmaceutical sciences. Pharm Res 2008;25(10):2216-30.

[38] Gao H, Matyjaszewski K. Synthesis of molecular brushes by "grafting onto" method: combination of ATRP and click reactions. J Am Chem Soc 2007;129 (20):6633-9.

[39] Block ML, Hong JS. Microglia and inflammation-mediated neurodegeneration: multiple triggers with a common mechanism. Prog Neurobiol 2005;76 (2):77-98. 
[40] Hanisch UK, Kettenmann H. Microglia: active sensor and versatile effector cells in the normal and pathologic brain. Nat Neurosci 2007;10(11):1387-94.

[41] Lalancette-Hebert M, Moquin A, Choi AO, Kriz J, Maysinger D. Lipopolysaccharide-QD micelles induce marked induction of TLR2 and lipid droplet accumulation in olfactory bulb microglia. Mol Pharm 2010;7(4): 1183-94.

[42] Maysinger D, Behrendt M, Lalancette-Hébert M, Kriz J. Real-time imaging of astrocyte response to quantum dots: in vivo screening model system for biocompatibility of nanoparticles. Nano Lett 2007;7:2513-20.
[43] abd-el- BassetE, Fedoroff S. Effect of bacterial wall lipopolysaccharide (LPS) on morphology, motility, and cytoskeletal organization of microglia in cultures. J Neurosci Res 1995;41(2):222-37.

[44] Block ML, Zecca L, Hong JS. Microglia-mediated neurotoxicity: uncovering the molecular mechanisms. Nat Rev Neurosci 2007;8(1):57-69.

[45] Choi CS, Savage DB, Kulkarni A, Yu XX, Liu ZX, Morino K, et al. Suppression of diacylglycerol acyltransferase-2 (DGAT2), but not DGAT1, with antisense oligonucleotides reverses diet-induced hepatic steatosis and insulin resistance. J Biol Chem 2007;282(31):22678-88. 